\title{
STRATEGIC PRIORITIES AND MECHANISMS TO STIMULATE FARM ENTERPRISES DEVELOPMENT
}

\author{
Vitalii Boiko', Liudmyla Hnatyshyn ${ }^{2}$
}

\author{
${ }^{1}$ Doctor of Economics Sciences, Lviv Polytechnic National University, S. Bandery str., 12, \\ Lviv, 79013, Ukraine. \\ Phone number.+38(032) 258-21-75. Email address vitalii.v.boiko@lpnu.ua \\ ${ }^{2}$ Doctor of Economics Sciences, Lviv National Agrarian University, V. Velykoho str, 1, Dubliany, \\ Zhovkivskyy district, Lviv region, 80381, Ukraine. \\ Phone number+38 (032) 224-29-30. Email address gnatluda@ukr.net
}

Received 3004 2020; Accepted 31082020

Farm enterprises are important actors in securing rural employment and income. The lack of efficiency of the farm enterprises functioning makes it difficult to establish a rational model of competitive and diversified agriculture. The purpose of the study is to develop strategic priorities and mechanisms to stimulate the development of farm enterprises. The research methodology stipulated the use of such methods as statistical grouping, indicative evaluation, comparative analysis, systematization, and strategic design. The authors evaluated structural imbalances of the farm enterprises development, analyzed their performance indicators and identified the obstacles that hinder the development of farming. The strategic priorities of the development of farm enterprises are justified in the article. Mechanisms for stimulating the development are proposed, including institutional and organizational, financial and investment, innovative and technological, social and personnel and environmental and economic ones.

Key words: farm enterprises, development, efficiency, mechanisms, agriculture.

JEL Code: Q01, Q12, Q13, Q18.

\section{Introduction.}

Farm enterprises are the important element of the diversified structure of agricultural production, the tool for leveling the display of monopolization of individual segments of the agricultural market and ensuring the competitive environment of the latter, the formation of the middle class of the rural population, increasing employment in rural areas, greening production and economic processes and enhancing the socio-economic development of rural areas. Actually, farm enterprises have to be a driving force and catalyst for the implementation of systemic changes in the rural areas, the structural adjustment of rural areas and the establishment of processes for their sustainable development in the context of the economic, social and environmental components. Farm enterprises are the key subject of the revitalization of the business environment in rural areas, the core for the development of the family type of economic management and the center for preserving the established customs and traditions of the rural population. At the same time, a number of unfavorable preconditions, including growing transformation processes, continued incompleteness of an agrarian reform, imbalances in the organizational and sectoral structure of the agribusiness complex, displays of unfair competition in the agricultural market, systematic lobbying of the commercial interests of powerful agricultural holding structures, irrational distribution of state financial support between agribusiness entities and negative migration processes in rural areas, cannot affect the development of farm enterprises positively.

\footnotetext{
Copyright (C) 2020. Published by Vytautas Magnus University. This is an open access article distributed under the terms of the Creative Commons Attribution Non-Commercial 4.0 (CC BY-NC 4.0) license, which permits unrestricted use, distribution, and reproduction in any medium provided the original author and source are credited. The material cannot be used for commercial purposes.
} 
In turn, this leads to a deterioration of the performance indicators of farm enterprises, an insufficient level of their technical and technological equipment, low rates of innovative development, limitation of the parameters for building up their production and economic potential, and a deterioration of competitive positions at the agricultural market.

The problems of farm development have been the subject of research of many scientists. The theoretical and applied aspects of the development of farm enterprises and effective methods for evaluating the results of their managing were analyzed by V. Zbarsky, S. Kalchenko and D. Eremenko in their studies. In particular, the authors note that, according to the social component, farm enterprises are a family-labor association of residents of a particular village, whose life and manners are aimed at producing the mass of commodities of food and generating income, and, therefore, at ensuring the existence of the household by itself and the welfare of its members. First of all, it is an economical and social unit of agricultural production, which can function both in an autonomous mode and in close cooperation with other agricultural and processing enterprises without losing its independence (Zbarsky, Kalchenko, Eremenko, 2016, p. 272-273). L. Marmul and O. Galtsova studied the problematic aspects of ensuring the efficiency of farm development. The scientists have identified the main determinants of the effectiveness of the development of farm enterprises, formed appropriate methods for assessing them and justified the resource reserves for increasing the capacity of these entities (Marmul, Galtsova, 2006). In turn, the problems of the formation and use of the labor potential of farms became the object of V. Stefanyuk's study. The author has structured the obstacles to the reproduction of the labor potential of farm enterprises under the conditions of negative migration processes and the deterioration of the quality of human capital in rural areas, as well as developed a system of measures to improve the efficiency of labor use of farms (Stefanyuk, 2016, $p$. 75-77). Quite worked out in the scientific literature is the establishment of the material and technical base for the functioning of farm enterprises are well studied in the scientific literature too (Ageeva, 2013, p. 167).

M. Burdeynyi positions farming as a driving, cultural and economic force, which provides not only the appropriate level of state food security, but also creates the prerequisites for stimulating the socio-economic development of rural territories (Burdeynyi, 1999, p. 23). O. Olshanska shares a similar approach in the process of studying farm enterprises and determines the food supply of the population as their most important function. It formalizes the valuable social role of farm enterprises in supporting the functioning of society, as well as ensuring the unity of agro-industrial and socioeconomic relations (Olshanska, 2013, p. 101). The increased attention to the development of farm enterprises results primarily from the aggravation of contradictions in the organizational and sectoral structures of agriculture. Actually, in this context O. Borodin and I. Prokop suggest that farm enterprises play an important role in overcoming structural deformations of the agricultural sector of the economy (Borodina, Prokopa, 2015, pp. 91-93). Farm enterprises form a resource basis for diversifying the risks of economic security of rural areas development (Boiko, Olishchyk, 2019, p. 104).

Adequate response to challenges, the search for opportunities to increase competitiveness and forecasting future parameters for the effective development of family farming in the European Union countries is a strategic guideline for the agenda of leading European institutions as a key basis for stimulating the socio-economic development of rural areas (Davidova, Thomson, 2014). The development of an effective model for the distribution of state support and the provision of subsidies to farm enterprises was the subject of A. Lorant and M. Fekete Farkas studies. The authors identified the shortcomings of subsidizing farm enterprises in the European Union, found untapped reserves for optimizing state support for farming and developed the proposals to improve the subsidizing of these entities (Lorant, Fekete Farkas, 2015). The identification of incentives for the development of farms from the perspective of taking into account the influence of the determinants of their internal (parameters of production potential, personal characteristics of the farmer, management methods, applied technologies) and external (legal basis for the development, access to credit, marketing conditions, state support system, foreign economic policy, informational and consultative support) 
environment are justified in the scientific research of A. Matthews (Matthews, 2014, p. 27). Such issues has been sufficiently elaborated as the cost minimization of farm enterprises by optimizing their production and business processes (da Silva, de Redenze, Pinto, 2018), innovative modernization and technological re-equipment of farm production capacities (Rose, Chilvers, 2018), implementation of differentiated marketing strategies in the context of strengthening the competitive position of farmers in the agricultural market (Bauman, McFadden, Jablonski Becca, 2018), the organization of organic farming in farm enterprises and its role in the process of the sustainable development support of rural areas in the European Union (Konstantinidis, 2018)

Despite the availability of scientific developments in the operation of the farm enterprises, some issues are still not sufficiently developed, for example, structural imbalances in land use of farm enterprises, identification of determinants for ensuring efficient production and economic activities, justification of effective tools for state support of farming, socio-economic and environmental components of the development of farming movement in rural areas. Thus, the processing of scientific and applied aspects of the functioning of farm enterprises under the conditions of increasing transformation processes, liberalization of the economy and socio-environmental imbalances, allowed us to define the main aim of the study - the justification of the strategic priorities and development of the mechanisms to enhance the development of farm enterprises. To achieve the main purpose of the study, the following tasks were identified: to assess the extent of concentration of agricultural lands that are used by the farmers, to analyze the performance indicators of production and economic activities of farms, to identify key obstacles to their functioning, to form a package of measures to implement strategic priorities and mechanisms to stimulate the development of farm enterprises. The object of the study is the production and economic processes of the development of farm enterprises as a fundamental component in building a competitive and socially just agricultural model. In turn, the subject of research is formed by a set of theoretical and applied foundations connected with the justification of strategic priorities and mechanisms to stimulate the development of farm enterprises.

The methodological basis of the study consisted of the following methods: statistical grouping (to structure farm enterprises by the size of their land use), indicative assessment (when analyzing the effectiveness of farms' production and economic processes), comparative analysis (in order to establish dynamic trends in the development of farm enterprises), systematization (to identify obstacles to development of farming), strategic design (in the development of strategic priorities and the mechanism to stimulate the development of farm enterprises). Formalization of an adequate methodology of scientific research provided the possibility of forming its reliable results and conclusions.

The expediency of achieving the main aim of the study is being updated in the context of incomplete agrarian reform in Ukraine, strengthening structural and sectoral imbalances in the development of the agricultural sector of the economy, rise in unemployment and worsening welfare of the rural population. Therefore, the justification of strategic priorities and the development of adequate mechanisms to stimulate the development of farm enterprises will ensure the formation of prerequisites for strengthening their competitive positions in the market, increasing the efficiency of production and business processes, improving the quality of agricultural products, overcoming imbalances in the agricultural sector of the economy, improving rural employment and evolvement of the middle class in the countryside.

\section{Results}

Farm enterprises are the most numerous category of agricultural producers, who, in the conditions of an unstable economic environment, have shown their ability to compete and have managed to create their own individual niche in the agricultural market. A distinctive feature and difference of farm enterprises from other organizational and legal forms of running business in the 
countryside is that the goal of the latter is to create the most expensive agribusiness in the shortest possible time based on maximizing productivity. On the other hand, farm enterprises, based on the specifics of managing and under the conditions of limited capital resources, seek to maximize profits in the long-term outlook, thereby ensuring the conditions of self-employment of the rural population and the principle of business continuity.

Today, the development of farm enterprises come up against a number of problems. First of all, the raw material export-oriented character of agriculture restrains the parameters of the development of farm enterprises, that contradicts the fundamental principles of diversified and multifunctional development of the agricultural sector of the economy and rural territories. The irrational imbalances in the overall structure of land use complicate the functioning of farms and the achievement of their production and economic potential (table 1). Despite the increase in the volume of farm land used by farm enterprises during the study period by 416.4 thousand ha $(9.7 \%$ in percentage terms), there is a steady negative trend towards a reduction in the number of farm enterprises among those using agricultural land - by 6779 units. In 2018, 19,003 farms (57.3\% in percentage terms) owned up to 50 hectares of farm lands, while their share of farm land ownership in the total structure of the land bank was only $10.1 \%$. Whereas in $2018,40.0 \%$ of the land bank was in use of 951 farms only (farm size 1000 hectares of agricultural land or more), whose share in the total number is only $2.7 \%$.

Table 1. Distribution of farms into groups by the size of agricultural land in Ukraine in 2010 and $2018 *$

\begin{tabular}{|c|c|c|c|c|c|c|c|c|c|c|}
\hline \multirow{3}{*}{$\begin{array}{c}\text { Groups of farm } \\
\text { enterprises by the } \\
\text { size of land area, ha }\end{array}$} & \multicolumn{4}{|c|}{ Number of enterprises } & \multicolumn{4}{|c|}{ Farm lands } & \multirow{2}{*}{\multicolumn{2}{|c|}{$\begin{array}{l}\text { Land accounted } \\
\text { for one farm, ha }\end{array}$}} \\
\hline & \multicolumn{2}{|c|}{ units } & \multicolumn{2}{|c|}{$\begin{array}{l}\text { from total } \\
\text { amount, } \%\end{array}$} & \multicolumn{2}{|c|}{ Thousand ha } & \multicolumn{2}{|c|}{$\begin{array}{c}\text { from total } \\
\text { area of farm } \\
\text { lands, } \%\end{array}$} & & \\
\hline & 2010 & 2018 & 2010 & 2018 & 2010 & 2018 & 2010 & 2018 & 2010 & 2018 \\
\hline $\begin{array}{l}\text { Enterprises that owned } \\
\text { farm lands }\end{array}$ & 37220 & 30441 & 89.6 & 91.8 & 4290.8 & 4707.2 & 100.0 & 100.0 & 115.3 & 154.6 \\
\hline Less than 3 ha & 2716 & 1342 & 6.5 & 4.0 & 5.7 & 2.8 & 0.1 & 0.1 & 2.1 & 2.0 \\
\hline $3.1-5.0$ & 2743 & 1430 & 6.6 & 4.3 & 11.6 & 6.1 & 0.3 & 0.1 & 4.2 & 4.3 \\
\hline $5.1-10.0$ & 3774 & 2301 & 9.1 & 6.9 & 29.7 & 18.1 & 0.7 & 0.4 & 7.9 & 7.9 \\
\hline $10.1-20.0$ & 4561 & 3498 & 11.1 & 10.6 & 70.5 & 54.4 & 1.6 & 1.2 & 15.5 & 15.6 \\
\hline $20.1-50.0$ & 12973 & 10432 & 31.3 & 31.5 & 493.1 & 394.8 & 11.5 & 8.3 & 38.0 & 37.8 \\
\hline $50.1-100.0$ & 4074 & 4160 & 9.8 & 12.6 & 289.5 & 298.4 & 6.8 & 6.3 & 71.1 & 71.7 \\
\hline $100.1-500.0$ & 4542 & 5111 & 10.9 & 15.4 & 1042.0 & 1193.3 & 24.3 & 25.4 & 229.4 & 233.5 \\
\hline $500.1-1000.0$ & 1013 & 1216 & 2.4 & 3.7 & 706.0 & 855.6 & 16.5 & 18.2 & 696.9 & 703.6 \\
\hline $1000.1-2000.0$ & 584 & 670 & 1.4 & 2.0 & 802.6 & 925.1 & 18.7 & 19.7 & 1374.3 & 1380.6 \\
\hline $2000.1-3000.0$ & 128 & 167 & 0.3 & 0.5 & 309.8 & 406.9 & 7.2 & 8.6 & 2420.3 & 2436.5 \\
\hline $3000.1-4000.0$ & 54 & 49 & 0.1 & 0.1 & 186.3 & 165.7 & 4.3 & 3.5 & 3450.0 & 3381.6 \\
\hline More than 4000.0 & 58 & 65 & 0.1 & 0.2 & 344.0 & 386.0 & 8.0 & 8.2 & 5931.0 & 5938.5 \\
\hline $\begin{array}{l}\text { Enterprises that have } \\
\text { no farm lands }\end{array}$ & 4304 & 2723 & 10.4 & 8.2 & - & - & - & - & - & - \\
\hline
\end{tabular}

*Source: calculations based on Agriculture of Ukraine in 2010 and 2018.

The stratification of the land use structure, in favor of large farm enterprises that bear the marks of large-scale commodity production entities, is accompanied by the loss of farm identity of these enterprises, a decrease of their social role in rural development and aggravation of environmental imbalances in the process of organizing the agricultural production. At the same time, the decrease in the number of small farm enterprises during the study period is a product of the irrational state policy of supporting farm enterprises and the lack of an effective institutional and legal mechanism for the transformation of non-commodity personal farm households into commodity farm enterprises. Obviously, the aggravation of the identified structural imbalances of the scale of farm management leads to the formation of a distorted farming model, reduces the competitiveness of these enterprises in the agricultural market and increases the risks of unbalanced nature management in rural areas. 
Despite the factor of increasing labor motivation, private ownership of the means of production did not provide farm enterprises with the sufficient prerequisites for the formation of high indicators of the efficiency of their production and economic activities. The aggravation of sectoral and environmental imbalances in the agricultural sector leads to the insufficient level of functioning of farm enterprises, given their resource capacities and production and economic potential, that constrains the development parameters of these farms and complicates their integration into the agricultural market (table 2).

Table 2. The main indicators of production and economic activities of farm enterprises in Ukraine in 2010, 2014-2018*

\begin{tabular}{|c|c|c|c|c|c|c|c|c|}
\hline \multirow[t]{2}{*}{ Indicators } & \multicolumn{6}{|c|}{ Year } & \multicolumn{2}{|c|}{$\begin{array}{c}2018 \text { as \% } \\
\text { over }\end{array}$} \\
\hline & 2010 & 2014 & 2015 & 2016 & 2017 & 2018 & 2010 & 2014 \\
\hline Number of farm enterprise, units & 41.5 & 33.1 & 32.3 & 33.7 & 34.1 & 33.2 & 80.0 & 100.3 \\
\hline $\begin{array}{l}\text { Agricultural products per } 100 \text { hectares of } \\
\text { agricultural land (at } 2010 \text { constant prices), } \\
\text { thousand UAH }\end{array}$ & 278.9 & 419.1 & 435.3 & 498.0 & 474.7 & 533.6 & 191.3 & 127.3 \\
\hline Level of profitability of agricultural production, $\%$ & 32.4 & 29.6 & 49.0 & 25.7 & 19.4 & 8.6 & $-23,8$ & $-21,0$ \\
\hline including crop production & 35.4 & 31.5 & 51.4 & 39.8 & 32.1 & 18.6 & $-16,8$ & $-12,9$ \\
\hline livestock production & 1.8 & 5.5 & 10.0 & 6.1 & 3.3 & 4.2 & 2.4 & -1.3 \\
\hline The share of agricultural land in use, $\%$ & 11.8 & 11.2 & 10.6 & 10.9 & 11.0 & 10.8 & -1.0 & -0.4 \\
\hline Share in the production of agricultural products, $\%$ & 6.3 & 7.6 & 7.9 & 8.7 & 8.7 & 9.3 & 3.0 & 1.7 \\
\hline
\end{tabular}

*Source: calculations based on Agriculture of Ukraine in 2010 and 2018.

According to statistics, a negative trend during 2010-2018 is a decrease in the number of farm enterprises by $20.0 \%$, which is due to the destabilizing influence of incomplete transformation processes and the insufficient competitiveness of farmers in the agricultural market, compared with other organizational and legal forms of management. Amid the growth in farm production, a decrease in the level of profitability of agricultural production in the crop and livestock industries is critical. Along with this, the share of agricultural production of farm enterprises in their total structure remains extremely low, amounting to $9.3 \%$ in 2018 .

A significant factor constraining the increase in production volumes and the efficiency of the functioning of farm enterprises is the insufficient level of their material and technical support. Outof-date agricultural machinery and low innovative technical and technological equipment of production facilities of farm enterprises makes it difficult to form their strong competitive advantages in the agricultural market, hinders the establishment of the production process with high added value and limits the performance parameters of these farms. At the same time, the increased economic instability hinders the free access of farm enterprises to attract credit resources to the production and economic process for innovative modernization of their production and economic capacities. Therefore, the farming system, in comparison with other organizational and legal forms in agriculture, still remains insufficiently investment-attractive, which makes it difficult to establish effective business processes for production.

The apparent bureaucracy and lobbyism from the representatives of powerful agricultural holding structures are the result of the irrational state policy on the development of farm enterprises. This leads to increased social stratification in the countryside, driving the farmers out from competition in the agricultural market, increased labor migration and stagnation of the socioeconomic development of rural areas. Thus, public goods, that should be created in the process of agricultural production (food security of the state, an adequate level of quality of life for the rural population, ecological balance, preserving biodiversity, etc.) are produced insufficiently, while the family type of farm functioning, which is in the best oriented towards creating these benefits and minimizing poverty among the rural population, does not receive the proper level of development stimulation (Zubar, 2015, p. 56). An aggravation in social tension in rural areas distorts socio- 
psychological motives for intensifying employment in agriculture, hinders the formation of new farm enterprises and also level neutralizes incentives for living in the countryside, especially among young people. In these conditions, farm enterprises face with the problems of the effective formation, renewal and reproduction of their labor potential, a shortage of qualified staffing and properly motivated workers.

A problematic aspect of the development of farm enterprises is the aggravation of environmental imbalances in rural ecosystems functioning. An increase in the anthropogenic load in the process of intensification of agricultural production, violation of scientifically based process charts for growing crops, non-observance of crop rotation during the management process, increasing structural imbalances of the crop and livestock industries, worsening the imbalance in the application of organic and mineral fertilizers makes it impossible to develop a rational model of farming in rural areas.

The existence of structural problems in the functioning of farm enterprises requires justification of strategic priorities to stimulate their development, the main of which are identified as follows:

1) overcoming structural imbalances in the land use of farm enterprises, improving the state policy of supporting the latter, designing a target model for the development of agriculture based on the farm mode;

2) increasing the investment attractiveness of farm enterprises, improving their access to credit resources and minimizing the risks of production and economic activity;

3) improving the material and technical base of farm enterprises, structural modernization of their production and economic capacities and reducing the energy intensity of production business processes;

4) development of the labor potential of farm enterprises, restructuring of the labor motivation system, improving the quality of human capital in rural areas;

5) the establishment of the fundamentals of rational nature management, balancing the production and industrial structure and the organization of zero waste production of farm enterprises.

In order to achieve justified strategic priorities to stimulate the development of farm enterprises, it is worth to focus on the implementation of such mechanisms as:

- institutional and organizational, which involves completing the process of transformation of land matters in agriculture by enshrining at the legislative level the target priority of the right to purchase agricultural land for farmers, preventing excessive concentration of land in the use of one owner by establishing rational scientifically based sizes of farm enterprises, positioning the farmers to be the most efficient and responsible owner and administrator of agricultural land, the formation of institutional prerequisites for increasing the production and economic capacities of small farm enterprises, building a system of motives and incentives for the transformation of non-commercial private farms into family farm enterprises, changes in the existing practice of providing state support in the agricultural sector in terms of changing the common orientation from the support of large agricultural producers to farm enterprises, reducing bureaucratization process of allocating budget subsidies to farmers and the level of state control over the use of funds;

- financial and investment, which provides for increasing the efficiency of the use of cash resources and managing the economic business processes of farm enterprises on the basis of stimulating the development of relations between these enterprises and banking institutions, including through the implementation of the state program for the allocation of favorable credit resources for farm enterprises with partial compensation of interest rates by means of the state budget funds, the formation of motives and incentives for farmers to reinvest the share of gains in the expanded reproduction processes, simplification of the taxation procedure for farm enterprises, the establishment of clear deadlines for value added tax refund, as well as the establishment of high priority for the refund of this tax for farm enterprises as target business entities in the agribusiness complex, the implementation of a set of measures to run an advertising campaign and promotion of the farm movement and the agricultural sector among potential investors, minimization of risks of 
farm enterprises through the sectoral diversification of their production and economic activities and the spread of the compulsory insurance practice of strategically important business processes;

- innovative and technological, the implementation of which is aimed at improving the technical and technological equipment of farm enterprises on the basis of increasing their level of supply with modern energy capacities through the use of financial and operational leasing tools, the implementation of state-regional programs for technical and technological modernization of farm enterprises using domestic agricultural engineering products, formation and development of rural service cooperatives among the farmers in order to provide services to its members timely and efficiently, especially during the peak period of seasonal work, improving the efficiency of the use of farm enterprise fixed assets and increasing capital productivity indicators by boosting the scale of labor automation in the crop and livestock sectors, introducing innovative process charts for cultivation of crops and keeping livestock, implementation of tools for precision farming and attracting information technologies to the production and economic process, increasing the area of agricultural land in the use of farm enterprises that are equipped with modern technologies of greenhouse farming and drip irrigation, increasing the elevator capacities of farm enterprises, developing production lines for freezing and organizing long-term storage of products;

- social and personnel, which involves improving the level of the farm enterprises staffing by organizing a holistic system of education, training and retraining of workers of these farms using the resource capacities of a network of information and consulting facilities (agricultural advisory services, agrarian higher education institutions, specialized scientific institutions); changes in existing approaches to motivating farm workers, on the basis of balancing tangible and intangible means of stimulating labor, primarily in terms of expanding the employment benefits and guarantees for workers (creating a system of bonus allowances and pays, especially during peak seasonal loads, providing additional days of annual paid vacation, holding employment in winter, providing the possibility of acquiring farm products at discount prices, etc.); implementing measures to develop human capital in rural areas, overcoming structural and age imbalances in countryside, stabilizing migration processes and promotion of living in rural areas, especially among young people, reducing displays of deviant and opportunist behavior in rural areas, creating incentives to attract funds of labor migrants to the establishment and development of new farm enterprises based on the family type of farming;

- ecological and economic, which involves the reduction of the anthropogenic load on the ecosystems of rural territories and the greening of agricultural production on the basis of ensuring the strategic fixation of farm enterprises on the organic farming segment, observing scientifically substantiated crop rotation systems in the process of growing crops, optimizing the structure of crop and livestock sectors ratio with regard to increasing gross shares of the latter (primarily cattle breeding, pig breeding, poultry farming, sheep and goat husbandry), balancing the application of mineral and organic fertilizers, the formation of closed production and business cycles for the disposal of agricultural waste (processing stubble, straw, animal waste, etc.), stimulating the development of own green energy capacities and their integration in power supply of food production and economic business processes of farm enterprises.

The implementation of the proposed strategic priorities and mechanisms to stimulate the development of farm enterprises should take place in the context of the implementation of complex coordinated measures of entities at the macro, meso and micro levels of national economy management. A pivotal aspect is the leveling of the dependence of the use of the priority set of mechanisms to stimulate the development of farm enterprises on the parameters of the political situation and possible changes in the vectors of influence on the formation of tools of the agricultural policy to support the farm movement and the establishment of the farm model of the agricultural system. Thus, if observing this approach, on the one hand, the prerequisites will be set for increasing the efficiency of production and economic processes of farm enterprises, improving the quality of their products and strengthening competitive positions in the agricultural market, and on the other 
hand, it will provide an impetus for structural change and completion of transformation processes in the agricultural sector economy in terms of the appearance of an effective owner in the countryside.

\section{Conclusions}

Farm enterprises play a strategically important role in ensuring the dynamic competitiveness of the agricultural sector, the creation of employment and incomes of rural population, the diversification of agricultural production and the sustainable development of rural areas. Consequently, the effectiveness of the development of farm enterprises determines not only economic, but also social parameters of the operation of agriculture. The development of farm enterprises is marked by such negative trends: a reduction in the number of farms during 2010-2018 by 8360 units. (by 20.1\%), the deepening of imbalances in the volume of farming land use, the presence of institutional restrictions on buildup of activities, the extremely low share of farm enterprises in the overall structure of agricultural production $(9.3 \%$ in 2018$)$, the deterioration in the profitability of agricultural production, unsatisfactory material and technical support of production and economic processes, increasing social tension in countryside and aggravation of ecological imbalance of nature management.

Overcoming the identified problems and stimulating the development of farm enterprises involves focusing on such strategic priorities as completing the institutional transformation of the agricultural sector of the economy, improving the economic parameters of the farm enterprises functioning, systemic modernization of production and economic processes, reproduction of the labor potential of farm enterprises, and the establishment of the basics of rational nature management. Achieving certain strategic priorities requires the implementation of such mechanisms to stimulate the development of farm enterprises: institutional and organizational (institutionalization of land matters, transformation of private households into farm enterprises, re-engineering of existing approaches to providing state support to farmers), financial and investment (intensification of relations between farm enterprises and banks, implementation of tools for profit reinvestment, insurance of production and economic activities of farm enterprises), innovative and technological (the introduction of financial and operational leasing tools, the creation of agricultural service cooperatives, the introduction of precision farming and information technologies in production), social and personnel (the organization of a system of education, training and retraining of personnel, better employment benefits for workers, improving the quality of human capital in rural areas), ecological and economic (organic farming, balancing of production in the industry, the formation of closed cycles of utilization and processing of production waste). The implementation of the developed mechanisms will establish the prerequisites for increasing the efficiency of the farm enterprises development, improving the quality of products and strengthening their competitiveness in the agricultural market.

\section{References}

Ageeva I.V. (2013). Material and technical support of farms. Scientific papers of Ukraine. No 2 (46): $165-170$.

Agriculture of Ukraine, 2018: Statistical yearbook (2011). State Statistic Service of Ukraine, Kyiv, $385 \mathrm{p}$.

Agriculture of Ukraine, 2018: Statistical yearbook (2019). State Statistic Service of Ukraine, Kyiv, $235 \mathrm{p}$.

Bauman A., McFadden. D. T., Jablonski Becca B. R. (2018). The Financial Performance Implications of Differential Marketing Strategies: Exploring Farms that Pursue Local Markets as a Core Competitive Advantage. Agricultural and Resource Economics Review. Vol. 47. Issue 3: 477-504.

Boiko V., Olishchyk P. (2019). Tools for ensuring economic security of rural areas development. Scientific Papers Series Management, Economic Engineering in Agriculture and Rural Development. Volume 19. Issue 3: P. 99-106. 
Borodina O.M., Porkopa I.V. (2015). Overcoming of structural deformations in Ukraine's agrarian sector: institutionalization and modernization of a small-scale agricultural production. Economy of Ukraine. No. 4: 88-96.

Burdeynyi I.M. (1999). Farming as an effective business pattern in countryside. The Economy of Agro-Industrial Complex. No. 5: 22-25.

da Silva M. F., da Silva A. C., de Redenze A. C., Pinto R. S. (2018). Zootechnical and economic evaluation of dairy farms: focus on cost management. Custos e Agronegocio on Line. Vol. 14: 182-212.

Davidova S., Thomson K. (2014). Family farming in Europe: challenges and prospects. European Parliament's Committee on Agriculture and Rural Development. 2014, 65 p.

Konstantinidis C. (2018). Capitalism in Green Disguise: The Political Economy of Organic Farming in the European Union. Review of Radical Political Economics. Vol. 50. Issue. 4: 830-852.

Lorant A., Fekete Farkas M. (2015). More insurance subsidies for European farmers - is it needed? Apstract. Vol. 9, N 4: 33-38.

Marmul L.O., Galtsova O.L. (2006). Efficiency of entrepreneurial activity of farm enterprises: monograph. Kyiv, National Scientific Center "Institute of Agricultural Economics", 204 p.

29.

Matthews A. (2014). Promoting Family Farming: The European Union. Great Insights. Vol. 3: 26-

Olshanska O.V. (2013). Influence of activity of farms upon development of agro-social systems. Problems of economy. No. 3: 97-101.

Rose D. C., Chilvers J. (2018). Agriculture 4.0: Broadening Responsible Innovation in an Era of Smart Farming. Frontiers in Sustainable Food Systems. Vol. 2. https://www.frontiersin.org/articles/10.3389/fsufs.2018.00087/full

Stefanyuk U.F. (2016). Improvement of formation and use of labor potential of farm enterprises. Black Sea Economic Studies, issue No. 3: 74-80.

Zbarsky V.K., Kalchenko S.V., Eremenko D.V. (2016). Optimization methodology for assessing the competitiveness of high-value farm family labor type. Scientific Bulletin of Uzhhorod University. Series Economics. No 1(2): 272-278.

Zubar I. V. (2015). Cooperational development of small farms on the basis of world experience. Innovative economy, No.4: 54-60. 